\title{
Gambaran bilirubin dan urobilinogen urin pada pasien tuberkulosis paru dewasa di RSUP Prof. Dr. R. D. Kandou Manado
}

\author{
${ }^{1}$ Faleriano Makay \\ ${ }^{2}$ Glady I. Rambert \\ ${ }^{2}$ Mayer F. Wowor
}

\author{
${ }^{1}$ Kandidat Skripsi Fakultas Kedokteran Universitas Sam Ratulangi Manado \\ ${ }^{2}$ Bagian Patologi Klinik Fakultas Kedokteran Universitas Sam Ratulangi Manado \\ Email: faleriano10makay@gmail.com
}

\begin{abstract}
Tuberculosis is an infectious disease caused by the bacillus Mycobacterium tuberculosis. Antituberculosis drugs prescribed to TB patients is hepatotoxic drug. Liver damage caused by side effects of the drugs will cause an alteration in urinary bilirubin and urobilinogen level. This study was aimed to obtain the profile of urinary bilirubin and urobilinogen in adult pulmonary tuberculosis patients at Prof. Dr. R. D. Kandou Hospital Manado from October to November 2016. This was an observational descriptive study. Samples obtained by using random sampling urine from all pulmonary tuberculosis patient that met the inclusion criteria. The results showed that according to urinary bilirubin and urobilinogen examination in 30 patients, most of them were in normal level. Only 6 out of 30 patients has bilirubinuria in this urinary bilirubin examination. In urinary urobilinogen examination, all results is in normal level. Conclusion: Urinary bilirubin and urobilinogen examination in this research was normal in general, bilirubinemia was found only in some patients.
\end{abstract}

Keywords: pulmonary tuberculosis, urinary bilirubin, urinary urobilinogen

\begin{abstract}
Abstrak: Tuberkulosis (TB) merupakan penyakit menular yang disebabkan oleh basil Mycobacterium tuberculosis. Obat antituberkulosis yang diberikan pada pasien TB bersifat hepatotoksik. Kerusakan hepar yang disebabkan oleh efek samping obat tersebut akan menyebabkan perubahan pada kadar bilirubin dan urobilinogen urin. Tujuan penelitian untuk mengetahui gambaran bilirubin dan urobilinogen urin pada pasien tuberkulosis paru dewasa di RSUP Prof. Dr. R. D. Kandou Manado. Jenis penelitian ialah deskriptif observasional, untuk mendapatkan data tentang bilirubin dan urobilinogen urin pada pasien tuberkulosis paru dewasa di RSUP. Prof. Dr. R. D. Kandou Manado pada Oktober-November 2016. Sampel penelitian adalah sampel urin sewaktu dari semua pasien tuberkulosis paru yang memenuhi kriteria inklusi. Hasil penelitian memperlihatkan berdasarkan pemeriksaan bilirubin dan urobilinogen urin pada 30 pasien, sebagian besar kadarnya normal. Hanya 6 dari 30 pasien yang mengalami bilirubinuria pada pemeriksaan bilirubin urin. Pada pemeriksaan urobilinogen urin semua hasil dalam batas normal. Simpulan: Pemeriksaan bilirubin dan urobilinogen urin pada umumnya normal, hanya beberapa pasien yang mengalami bilirubinuria.
\end{abstract}

Kata kunci: tuberkulosis paru, bilirubin urin, urobilinogen urin

Tuberkulosis (TB) merupakan penyakit menular yang disebabkan oleh basil Mycobacterium tuberculosis. Tuberkulosis (TB) merupakan masalah kesehatan global utama. Pada tahun 2014, diperkirakan ada 9,6 juta kasus TB baru: 5,4 juta pada lakilaki, 3,2 juta di kalangan perempuan, dan 1,0 juta anak-anak. ${ }^{1}$ Indonesia merupakan 
negera dengan prevalensi TB ketiga tertinggi di dunia setelah China dan India. ${ }^{2}$ Prevalensi penduduk Sulawesi Utara yang terdiagnosis TB paru pada tahun 2013 adalah 0,3 persen. ${ }^{3}$

Program pengobatan TB di Indonesia sudah mengacu pada program Directly Observed Treatment Short Course Strategy (DOTS) yang didasarkan pada rekomendasi WHO. Lini pertama obat anti-TB terdiri dari isoniazid $(\mathrm{H})$, rifampisin $(\mathrm{R})$, pirazinamid $(\mathrm{Z})$, etambutol $(\mathrm{E})$, dan streptomisin (S). Dalam pemakaian obatobat anti tuberkulosis tidak jarang ditemukan efek samping yang mempersulit sasaran pengobatan. Ketiga OAT yaitu isoniazid, rifampisin, dan pirazinamid merupakan obat yang dapat menyebabkan hepatotoksisitas. $^{2}$

Pada keadaan hepatotoksik terdapat kerusakan sel hati yang akan menyebabkan terjadinya mikro-obstruksi di hepar. Obstruksi akan menyebabkan berkurangnya bilirubin yang diekskresikan ke dalam usus sehingga menyebabkan pembentukan urobilinogen berkurang. Sementara bilirubin terkonjugasi dalam hepar akan masuk kembali ke dalam darah karena pengosongan langsung ke saluran limfe yang meninggalkan hepar serta pecahnya kanalikuli biliaris yang terbendung. Bilirubin terkonjugasi dalam darah kemudian akan dieksresikan ginjal ke dalam urin. Pada urin akan ditemukan menurunnya kadar urobilinogen urin dan terdapat bilirubin urin. ${ }^{4}$ Kadar bilirubin dan urobilinogen urin dapat diperiksa melalui urinalisis secara kimiawi dengan menggunakan uji strip reagen. ${ }^{5}$

Penelitian ini bertujuan untuk Untuk mengetahui gambaran bilirubin dan urobilinogen urin pada pasien tuberkulosis paru dewasa di RSUP Prof. Dr. R. D. Kandou Manado.

\section{METODE PENELITIAN}

Desain penelitian yang digunakan adalah penelitian deskriptif observasional. Penelitian ini dilaksanakan di Poliklinik Paru dan rawat inap bagian Ilmu Penyakit Dalam RSUP Prof. Dr. R. D. Kandou
Manado pada bulan Oktober-November 2016. Sampel penelitian ini adalah sampel urin sewaktu dari semua pasien tuberkulosis paru dewasa dalam kurun waktu dan kriteria yang telah ditentukan dengan cara non-probability sampling jenis consecutive sampling. Data yang diperoleh kemudian dikumpulkan, diolah dalam bentuk tabel, dan selanjutnya disusun secara komputerisasi menggunakan program Microsoft Office Excel.

\section{HASIL PENELITIAN}

Pada penelitian yang dilaksanakan di Poliklinik Paru dan rawat inap bagian Ilmu Penyakit Dalam RSUP Prof. Dr. R. D. Kandou Manado dengan total sampel berjumlah 30 pasien, terdiri dari 20 pasien $(67,3 \%)$ laki-laki dan perempuan 10 orang $(33,3 \%)$ perempuan.

Distribusi pasien berdasarkan usia yaitu: terdapat 4 orang $(13,3 \%)$ pada kelompok usia 18-25 tahun, 4 orang $(13,3 \%)$ pada kelompok usia 26-35 tahun, 8 orang $(26,7 \%)$ pada kelompok usia 36-45 tahun, 6 orang $(20,0 \%)$ pada kelompok usia 46-55 tahun, 6 orang $(20,0 \%)$ pada kelompok usia 56-65 tahun, dan 2 orang $(6,7 \%)$ kelompok usia 66-75 tahun dari total jumlah pasien TB paru yang menjadi sampel penelitian.

Tabel 1. Distribusi pasien berdasarkan jenis kelamin dan usia

\begin{tabular}{lcc}
\hline Variabel & Jumlah & $\%$ \\
\hline Jenis kelamin & & \\
Laki-Laki & 20 & $66.7 \%$ \\
Perempuan & 10 & $33.3 \%$ \\
Usia & & \\
$18-25$ & 4 & $13.3 \%$ \\
$26-35$ & 4 & $13.3 \%$ \\
$36-45$ & 8 & $26.7 \%$ \\
$46-55$ & 6 & $20.0 \%$ \\
$56-65$ & 6 & $20.0 \%$ \\
$66-75$ & 2 & $6.7 \%$ \\
\hline
\end{tabular}

Pada penelitian didapatkan dari seluruh pasien TB paru yang menjadi subjek 
penelitian, terdapat 4 orang dengan hipertensi, 5 orang dengan diabetes mellitus, 5 orang dengan hiperurisemia, dan 6 orang dengan penyakit ginjal.

Tabel 2. Distribusi pasien berdasarkan penyakit penyerta

\begin{tabular}{lc}
\hline Penyakit penyerta & Total \\
\hline Hipertensi & 4 \\
DM & 5 \\
Hiperurisemia & 5 \\
Gangguan ginjal & 6 \\
\hline
\end{tabular}

Pada penelitian didapatkan hasil dari total 30 pasien yang menjalani pemeriksaan, didapatkan 24 pasien $(80,0 \%)$ dengan kadar bilirubin urin negatif dan 6 pasien $(20,0 \%)$ mengalami bilirubinuria dalam jumlah kadar kecil (small).

Tabel 3. Distribusi hasil pemeriksaan bilirubin urin

\begin{tabular}{lcc}
\hline \multicolumn{1}{c}{ Kadar Bilirubin Urin } & Total & \% \\
\hline Negatif (normal) & 24 & $80 \%$ \\
Small (bilirubinuria) & 6 & $20 \%$ \\
Large (bilirubinuria) & 0 & $0 \%$ \\
Moderate (bilirubinuria) & 0 & $0 \%$ \\
\multicolumn{1}{c}{ Total } & 30 & $100 \%$ \\
\hline
\end{tabular}

Tabel 4. Distribusi hasil pemeriksaan urobilinogen urin

\begin{tabular}{ccc}
\hline Kadar Urobilinogen Urin & Total & $\mathbf{\%}$ \\
\hline 0,2 (Normal) & 28 & $93.33 \%$ \\
1,0 (Normal) & 2 & $6.67 \%$ \\
2,0 & 0 & $0 \%$ \\
4,0 & 0 & $0 \%$ \\
8,0 & 0 & $0 \%$ \\
Total & 30 & $100 \%$ \\
\hline
\end{tabular}

Pada penelitian didapatkan hasil dari total 30 pasien yang menjalani pemeriksaan, didapatkan 28 pasien dengan kadar urobilinogen urin sebesar 0,2 E.U./dL dan terdapat 2 pasien dengan kadar urobilinogen urin sebesar 1,0 E.U./dL. Kadar urobilinogen urin 30 pasien dalam kisaran normal, yaitu 0,1-1,0 E.U./dL

Tabel 5. Distribusi bilirubinuria berdasarkan jenis kelamin, usia

\begin{tabular}{ccc}
\hline Variabel & Jumlah & $\%$ \\
\hline Jenis kelamin & & \\
Laki-Laki & 4 & $66.7 \%$ \\
Perempuan & 2 & $33.3 \%$ \\
Usia (tahun) & & \\
$18-25$ & 1 & $16.7 \%$ \\
$26-35$ & 0 & $0.0 \%$ \\
$36-45$ & 3 & $50.0 \%$ \\
$46-55$ & 1 & $16.7 \%$ \\
$56-65$ & 1 & $16.7 \%$ \\
66-75 & 0 & $0.0 \%$ \\
Lama pengobatan & & \\
(bulan ke-) & & \\
I & 3 & $50.0 \%$ \\
II & 1 & $16.7 \%$ \\
III & 0 & $0.0 \%$ \\
IV & 1 & $16.7 \%$ \\
V & 0 & $0.0 \%$ \\
VI & 0 & $0.0 \%$ \\
>VI & 1 & $16.7 \%$ \\
Penyakit Penyerta & & \\
DM & 2 & $33.3 \%$ \\
Gangguan Ginjal & 1 & $16.7 \%$ \\
Tanpa penyakit & & \\
penyerta & 3 & $50.0 \%$ \\
\hline
\end{tabular}

Berdasarkan Tabel 5, dari 6 pasien yang mengalami bilirubinuria terdapat 4 pasien $(66,7 \%)$ laki-laki dan 2 pasien $(33,3 \%) \quad$ perempuan. Berdasarkan kelompok usia, dari 6 pasien yang mengalami bilirubinuria terdapat 1 pasien $(16,7 \%)$ kelompok usia $18-25$ tahun, 3 pasien $(50,0 \%)$ kelompok usia 36-45 tahun, terdapat 1 pasien $(16,7 \%)$ kelompok usia 46-55 tahun, dan terdapat 1 pasien $(16,7 \%)$ kelompok usia 56-65 tahun.

Berdasarkan lama pengobatan, dari 6 pasien yang mengalami bilirubinuria terdapat 3 pasien $(50,0 \%)$ pengobatan bulan pertama, 1 pasien $(16,7 \%)$ pengobatan bulan kedua, terdapat 1 pasien $(16,7 \%)$ kelompok pengobatan bulan keempat, dan terdapat 1 pasien $(16,7 \%)$ kelompok pengobatan di atas bulan keenam.

Berdasarkan ada tidaknya penyakit 
penyerta, dari 6 pasien yang mengalami bilirubinuria terdapat 2 pasien $(33,3 \%)$ dengan diabetes mellitus, 1 pasien $(16,7 \%)$ dengan penyakit ginjal, dan 3 pasien $(50 \%)$ tanpa penyakit penyerta.

\section{BAHASAN}

Berdasarkan data yang diperoleh pada Tabel 1, dapat dilihat bahwa kelompok usia 36-45 tahun merupakan kelompok usia terbanyak yang menderita TB paru. Hal ini sesuai dengan data dari Pedoman Nasional Pengendalian TB Kemenkes 2014 yang menunjukkan bahwa sekitar $75 \%$ pasien TB paru berada pada usia produktif yaitu, 20-49 tahun. Infeksi kuman tuberkulosis dapat terjadi pada segala usia tetapi kebanyakan penyakitnya berkembang pada masa dewasa muda. Hal ini terjadi karena pada usia produktif setiap orang akan cenderung beraktivitas tinggi, sehingga kemungkinan untuk terpapar kuman mikobakterium tuberkulosis lebih besar. ${ }^{6}$

Berdasarkan distribusi jenis kelamin, secara keseluruhan distribusi pasien rawat jalan dan pasien rawat inap dapat dilihat dari 30 pasien TB paru, terdapat 20 orang $(66,7 \%)$ laki- laki dan 10 orang $(33,3 \%)$ perempuan. Hal ini sejalan dengan penelitian Simamora $\mathrm{dkk}^{7}$ terhadap pasien TB rawat inap di RSUP Prof. Dr. R. D. Kandou yang memperoleh hasil $65,9 \%$ pasien laki-laki dan $34,1 \%$ pasien perempuan. Berdasarkan kelompok jenis kelamin didapatkan bahwa pada pasien tuberkulosis paru pasien laki-laki lebih banyak dari pasien perempuan. Hal ini diduga akibat perbedaan pajanan dan risiko infeksi. Laki-laki sebagian besar mempunyai kebiasaan merokok, minum alkohol, dan menggunakan obat-obatan terlarang. Selain itu, faktor aktivitas dan pekerjaan yang lebih pada laki-laki juga berpengaruh. ${ }^{8}$

Berdasarkan distribusi penyakit penyerta, terdapat 4 orang dengan hipertensi, 5 orang dengan diabetes mellitus, 5 orang dengan hiperurisemia, dan 6 orang dengan penyakit ginjal. Diabetes mellitus merupakan faktor risiko terjadinya tuberkulosis. Pada pasien DM akan terjadi penurunan imunitas sehingga lebih berisiko untuk terinfeksi Mycobacterium tuberculosis. ${ }^{9}$ Hiperurisemia merupakan salah satu efek samping dari terapi OAT. Etambutol dan pirazinamid merupakan OAT yang dapat menyebabkan peningkatan asam urat. Pada penelitian di Kasturba Chest Hospital, India, didapatkan hiperurisemia sebanyak 51 dari 73 (69.9\%) pasien yang menerima terapi OAT. ${ }^{10}$ Penyakit ginjal merupakan faktor risiko terjadinya tuberkulosis. Pada PGK terjadi disfungsi sistem imun berupa depressed cell-mediated immunity (CMI) sehingga pasien dengan PGK memiliki risiko 10-15 kali lebih besar untuk mendapatkan infeksi, termasuk infeksi Mycobacterium tuberculosis. ${ }^{11}$

Berdasarkan hasil pemeriksaan pada Tabel 3, dari 30 pasien TB paru yang melakukan pemeriksaan bilirubin urin, terdapat 6 pasien $(20,0 \%)$ mengalami bilirubinuria dan 24 pasien $(80,0 \%)$ dengan kadar bilirubin urin negatif (normal). Bilirubinuria pada 6 pasien tersebut dalam jumlah kadar kecil (small). Hanya sebagian kecil pasien yang mengalami peningkatan kadar bilirubin urin. Kadar bilirubin urin akan meningkat jika terjadi efek samping hepatotoksik yang akan menyebabkan hepatitis imbas obat. ${ }^{12}$ Hepatitis imbas obat akan mengakibatkan terjadinya obstruksi intra-hepatik yang akan menyebabkan peningkatan bilirubin terkonjugasi di darah serta penurunan sekresi bilirubin terkonjugasi ke usus. ${ }^{4}$ Bilirubinuria adalah penanda akut penyakit hepatoseluler. Adanya bilirubin di urin selalu mendahului tanda-tanda lain dari kelainan fungsi hepar, seperti jaundice. ${ }^{5}$ Peningkatan kadar bilirubin urin yang tidak terlalu signifikan pada penelitian ini tidak terlalu berbeda dengan penelitian Syakya $\mathrm{dkk}^{13}$ yang menemukan hanya 4 dari 50 pasien $(8 \%)$ yang mengalami hepatotoksik akibat terapi OAT.

Berdasarkan Tabel 4, kadar urobilinogen urin pada 30 subjek penilitian dalam kisaran normal, yaitu 0,1-1,0 E.U./dL. Kekurangan dari pemeriksaan urobilinogen urin dengan menggunakan 
reagen strip adalah tidak dapat memperlihatkan berkurangnya kadar atau tidak adanya urobilinogen dalam urin. Hal ini dikarenakan pemeriksaan dengan strip reagen hanya membaca kadar urobilinogen urin terendah pada kisaran 0,2 E.U./dL sementara urobilinogen urin dianggap mengalami penurunun kadar jika kurang dari 0,1 E.U./dL. ${ }^{14}$ Meskipun penurunan urobilinogen urin tidak dapat dideteksi dengan pemeriksaan urin, penurunan atau tidak adanya urobilinogen di urin penting sebagai penanda adanya obstruski saluran empedu. ${ }^{15}$ Pada hepatotoksik dini, terdapat kerusakan sel hati yang ringan, kadar urobilinogen urin akan meningkat walaupun kadar bilirubin serum tidak berubah. Pada keadaan hepatotoksik kemudian akan terjadi mikro-obstruksi di hepar. Obstruksi akan menyebabkan berkurangnya bilirubin yang diekskresikan melalui getah empedu ke dalam usus sehingga menyebabkan pembentukan urobilinogen berkurang. ${ }^{4}$ Hal ini akan menyebabkan menurunnya atau tidak adanya bilirubin di urin. Namun, hal ini tidak dapat diketahui melalui pemeriksaan rutin. ${ }^{14}$

Berdasarkan jenis kelamin, diperoleh dari 6 pasien yang mengalami bilirubinuria terdapat 4 pasien $(66,7 \%)$ laki-laki dan 2 pasien $(33,3 \%)$ perempuan. Pasien laki-laki lebih banyak dibandingkan perempuan. Hal ini sejalan dengan penilitian Naqvi dkk ${ }^{16}$ yang menemukan 192 laki-laki $(69,0 \%)$ dan 86 perempuan $(30,93 \%)$ yang mengalami hepatitis imbas OAT. Hasil ini berbeda dengan penelitian Shakya $\mathrm{dkk}^{13}$ yang menemukan 1 pasien laki-laki dan 3 pasien perempuan yang mengalami hepatitis imbas OAT. Perempuan dianggap memiliki faktor risiko lebih besar karena variasi farmakokinetik dan status acytylators yang lambat. ${ }^{16}$

Berdasarkan kelompok usia, kelompok usia 36-45 tahun merupakan kelompok usia terbanyak yang mengalami bilirubinuria sebanyak 3 pasien $(50,0 \%)$. Hal ini sejalan dengan penilitian Naqvi $\mathrm{dkk}^{16}$ yang menemukan kejadian hepatitis imbas OAT sebagian besar pada usia lebih dari 37 tahun (64,38\%). Menurut Lima $\mathrm{dkk}^{17}$ hubungan antara usia dan kejadian hepatitis imbas obat tidak ditemukan hubungan signifikan.

Berdasarkan lama pengobatan, sebagian besar pasien yang mengalami bilirubinuria adalah pasien pengobatan bulan pertama, yaitu sebanyak 3 pasien (50\%). Hal ini sejalan dengan penelitian Rifai dkk $^{18}$ di RSUD Dr. Saiful Anwar Malang yang menemukan bahwa hampir $88 \%$ pasien mengalami hepatitis imbas OAT pada 2 bulan pertama terapi dengan proporsi terbesar terjadi pada bulan pertama $(52 \%)$. Bilirubinuria ditemukan lebih banyak pada pasien pengobatan bulan pertama disebabkan karena bulan I dan II adalah fase intensif pemberian obat dimana dilakukan pemberian 4 obat sekaligus selama 2 bulan. $^{2}$

Ditinjau dari ada tidaknya penyakit penyerta, diperoleh dari 6 pasien yang mengalami bilirubinuria terdapat 2 pasien $(33,3 \%)$ dengan diabetes mellitus, 1 pasien $(16,7 \%)$ dengan penyakit ginjal, dan 3 pasien $(50 \%)$ tanpa penyakit penyerta. DM dan penyakit ginjal merupakan faktor risiko terjadinya TB tetapi tidak memiliki peranan langsung dalam terjadinya bilirubinuria. ${ }^{9,11}$ Hal ini menunjukkan bahwa kemungkinan bilirubinuria diakibatkan oleh efek hepatotoksik OAT pada pasien TB.

\section{SIMPULAN}

Berdasarkan hasil penelitian yang dilakukan di RSUP Prof. Dr. R.D. Kandou Manado maka dapat disimpulkan bahwa pada penyakit tuberkulosis paru hasil pemeriksaan bilirubin dan urobilinogen urin pada umumnya normal, hanya terdapat 6 dari 30 pasien yang mengalami bilirubinuria.

\section{SARAN}

Pada penelitian selanjutnya jumlah sebaiknya jumlah sampel yang digunakan lebih banyak untuk menghindari terjadinya bias penelitian. Penelitian selanjutnya sebaiknya menggunakan metode analitik agar dapat melihat hubungan bilirubin urin dan urobilinogen urin dengan tuberkulosis 
paru. Selain itu, perlu informasi lebih lengkap tentang data pasien atau subjek penelitian.

\section{DAFTAR PUSTAKA}

1. World Health Organization. Global tuberculosis report 2015

2. Amin Z, Bahar A. Tuberkulosis. Dalam: Setiawati S, Alwi I, Sudoyo AW, Simadibrata KM, Setiyohadi B, Syam $\mathrm{AF}$, editor. Buku ajar ilmu penyakit dalam. Edisi ke-6. Jakarta: InternaPublishing; 2014:1, h. 863-81.

3. Kementerian Kesehatan RI. Riset kesehatan dasar 2013. Jakarta: Badan Penelitian dan Pengembangan Kesehatan Kemenkes RI; 2013.

4. Guyton AC, Hall JE. Textbook of Medical Physiology. $12^{\text {th }}$ ed. Philadelphia: Elsevier; 2011, p. 303-43,840-2.

5. Fischbach FT, Dunning MB. A Manual of Laboratory and Diagnostic Tests. $8^{\text {th }}$ ed. China: Wolters Kluwers Health; 2009, p. 184-92,224-7.

6. Kementerian Kesehatan RI. Pedoman nasional pengendalian tuberkulosis; 2014.

7. Simamora V, Tjitrosantoso HM, Wiyono WI. Evaluasi pengobatan obat antituberkulosis di instalasi rawat inap BLU RSUP Prof. Dr. R. D. Kandou Manado periode januaridesember 2010. Manado: Universitas Sam Ratulangi; 2010.

8. Lönnroth K, Williams BG, Stadlin S, Jaramillo E, Dye C. Alcohol use as a risk factor for tuberculosis. BMC Public Health. 2008;8:1-12.

9. Dooley KE, Chaisson RE. Tuberculosis and diabetes mellitus: convergence of two epidemics. NIH. 2009;9:737-46.

10. Khanna BK, Kumar J. Hyperuricemic effect of ethambutol and pyrazinamide administered concomitantly. Ind. J. Tub. 1991;38:21-4.

11. Mimi N, Medregoniu D, Olteanu M, Golli A, Maceseanu A, Medregoniu R. Tuberculosis and chronic renal failure; therapy patterns. Curr Health Sci J. 2011;37(2):106.

12. Pandit A, Scahdeva T, Bafna P. Druginduced hepatotoxicity. Journal of Applied Pharmaceutal Science. 2012;2(5):233-43.

13. Shakya R, Rao BS, Shrestha B. Evaluation of risk factor for antituberculosis drugs induced hepatotoxicity in nepalese population. Kathmandu University Journal of Science, Engineering, and Technology. 2006;2:1-8.

14. Siemens Healthcare Diagnostics Inc. Siemens Multistix ${ }^{\circledR}$ 10. Tarrytown; 2010.

15. Brunner, Suddarth. Brunner \& Suddarth's Handbook of Laboratory and Diagnostic Test. Philadelphia: Wolters Kluwers Health; 2010, pp. 17-21,84-7.

16. Naqvi IH, Mahmood K, Talib A, Mahmood A. Antitiberculosis drugs induced liver injury: an ignored fact, assessment of frequency, patterns, severity, and risk factors. OJGas. 2015;5:173-84.

17. Lima MFS, Melo HRL. Hepatotoxicity induced by antituberculosis drugs among patients coinfected with HIV and tuberculosis. Cad Saude Publica. 2012;28(4):698-708.

18. Rifai A, Herlianto B, Mustika S, Pratomo B, Supriono. Insiden dan gambaran klinis hepatitis akibat obat anti tuberkulosis di rumah sakit umum daerah dr. saiful anwar malang. Jurnal Kedokteran Brawijaya. 2015;28:23841. 